\title{
Edukasi Kontrasepsi IUD pada Akseptor KB di Rt. 9 Kelurahan Pasar Lama Wilayah Kerja Puskesmas S.Parman Kota Banjarmasin
}

\author{
Husnul Khatimatun Inayah ${ }^{1 *}{ }^{*}$ Netty $^{2}$, Nurul Indah Qariati ${ }^{3}$, Ari Widyarti ${ }^{4}$ \\ 1, 2, 3,4 Fakultas Kesehatan Masyarakat, Universitas Islam Kalimantan (UNISKA) MAB Banjarmasin \\ *Email : husnulhlf@gmail.com
}

Submitted : 26/02/2020

Accepted: 05/03/2020

Published: 16/06/2020

\begin{abstract}
The total population of Indonesia in 2016 was 258,986 people with a population increase of 3.24 million people per year. The efforts of the government to reduce the rate of population growth by the number of births through the Family Planning program and to maintain the age of first marriage. The most dominant contraceptive method in Indonesia is the short-term contraceptive method, namely injections (52.8\%) and pills (23, 77\%). Whereas Contraception in the Womb or IUD (IUD) $(4.73 \%)$, which has good effectiveness and long term contraception is in great demand. Low IUD allocation. External and internal factors. internal factors include incorrect knowledge about the IUD and low education. The target of education is the mother of acceptors in RT 9 Kelurahan, Pasar Lama, working area in the Puskesmas S. Parman, Banjarmasin. Where active KB acceptors are 38 people, who use contraceptive pills 20 people, injections 18 people, condoms and IUDs were absent during 2018 and January - August 2019, active KB acceptors 39 people, who used contraceptive pills 21 people, injections 18 people, condoms and the IUD does not exist. The purpose of this activity is to increase the knowledge of family planning acceptors about contraception in general and IUD contraception in particular. The method used is an explanation using flipcharts and questions and answers. As a result of community service activities, an increase in knowledge about IUD contraception occurred.
\end{abstract}

Keyword : acceptor, education, IUD

\begin{abstract}
Abstrak
Jumlah penduduk Indonesia pada tahun 2016 sebesar 258.986 jiwa dengan laju pertambahan penduduk mencapai 3,24 juta jiwa pertahun. Upaya pemeruntah untuk menekan laju pertambahan penduduk dengan menurunkan jumlah kelahiran melalui program Keluarga Berencana dan penundaan umur pernikahan pertama. Metode Kontrasepsi yang paling dominan di Indonesia adalah metode kontrasepsi jangka pendek yaitu suntikan $(52,8 \%)$ dan pil $(23,77 \%)$. Rendahnya cakupan AKDR dipengaruhi faktor eksternal dan internal. faktor internal termasuk didalamnya pengetahuan yang salah tentang AKDR dan Pendidikan yang rendah (Suniarti,dkk 2013). Sasaran Edukasi adalah ibu akseptor di RT 9 Kelurahan Pasar lama wilayah Kerja di Puskesmas S.Parman Kota Banjarmasin. Dimana akseptor KB aktif 38 orang, yang menggunakan kontrasepsi pil 20 orang, suntikan 18 orang, kondom dan IUD tidak ada selama Tahun 2018 dan Januari - Agustus 2019, akseptor KB aktif 39 orang, yang menggunakan kontrasepsi pil 21 orang, suntikan 18 orang, kondom dan IUD tidak ada.Tujuan dari kegiatan ini adalah meningkatkan Pengetahuan akseptor KB tentang kontasepsi secara umum dan kontasepsi IUD secara khususnya. Metode yang digunakan adalah penyuluhan dengan menggunakan media lembar balik dan tanya jawab. Hasil kegiatan Pengabdian kepada masyarakat ini terjadi peningkatan pengetahuan tentang Kontrasepsi IUD.
\end{abstract}

Kata Kunci : akseptor, edukasi, IUD 


\section{PENDAHULUAN}

Jumlah penduduk Indonesia pada tahun 2016 sebesar 258.986 jiwa dengan laju pertambahan penduduk mencapai 3,24 juta jiwa pertahun. Upaya pemerintah untuk menekan laju pertambahan penduduk dengan menurunkan jumlah kelahiran melalui program Keluarga Berencana dan penundaan umur pernikahan pertama (KemenKes RI, 2017). Program KB bertujuan membentuk keluarga kecil, sehat, perpendidikan yang sejahtera dengan cara menunda atau menjarangkan kelahiran dengan menggunakan alat kontrasepsi.

Metode Kontrasepsi yang paling dominan di Indonesia adalah metode kontrasepsi jangka pendek yaitu suntikan $(52,8 \%)$ dan pil (23,77\%). Kontrasepsi yang kurang diminati adalah kontrasepsi jangka Panjang yaitu implant (11,20\%), Alat kontrasepsi dalam Rahim (4,73\%), Metode Kontap Wanita (3,54\%) dan Metode kontap pria $(0,64 \%)$. Fakta dilapangan suntikan dan pil merupakan metode kontrasepsi yang paling banyak menjadi penyumbang angka drop aut (KemenKes RI, 2013).

Menurut Mappawere (2016), akseptor suntikan dan pil yang dropout, sehingga kontrasepsi yang dianjurkan adalah kontrasepsi jangka Panjang terutama AKDR, karena keunggulannya di banding metode kontrasepsi lain diantranya sangat efektif mencegah kehamilan hingga 99\%, lebih praktis sebab hanya sekali pemakaian, harga terjangkau, aman untuk ibu menyusui, tidak meningkatkan $\mathrm{BB}$ dan direkomendasikan ibu dengan penyakit tertentu.

Target Penggunaan AKDR di Indonesia Tahun 2016 target 10,6 dan cakupan 4,8\%. Tahun 2017 target $34,6 \%$ dan cakupan $12,0 \%$ (BKKBN, 2017). Rendahnya cakupan AKDR dipengaruhi oleh pengetahuan tentang KB modern.Menurut KemenKes (2013) AKDR cenderung lebih diketahui seiring meningkatnya level pendidikan seseoarang.

Berdasarkan Dinas Kota Banjarmasin memiliki 22 Puskesmas. Puskesmas S. Parmam memiliki Akseptor KB aktif 645 orang,tahun 2018 yang menggunakan kontrasepsi pil sebanyak 305 orang, suntikan sebanyak 292 suntikan dan kondom sebanyak 48 orang, sedangkan IUD tidak ada. Tahun 2019 dari bulan Januari - Agustus dari $575 \mathrm{~KB}$ aktif yang menggunakan kontrasepsi pil 257 dan suntikan 282, kondom 38 orang dan IUD 1 orang.

RT 9 kelurahan Pasar lama wilayah Kerja di Puskesmas S.Parman Kota Banjarmasin. Dimana akseptor KB aktif 38 orang, yang menggunakan kontrasepsi pil 20 orang, suntikan 18 orang, kondom dan IUD tidak ada selama Tahun 2018 dan Januari - agustus 2019, akseptor KB aktif 39 orang, yang menggunakan kontrasepsi pil 21 orang, suntikan 18 orang, kondm dan IUD tidak ada. Rendahnya cakupan AKDR dipengaruhi factor eksternal dan internal. Faktor eksternal adalah rumitnya pemasangan AKDR dan pengalaman aksepor AKDR, faktor internal termasuk didalamnya pengetahuan salah tentang AKDR dan Pendidikan yang rendah (Suniarti,dkk 2013). Menurut Safitri (2020) masih ada juga pasangan usia subur yang tidak menggunakan alat kontrasepsi dengan berbagai alasan yaitu; tidak tahu 17,5\%, tidak nyaman $61,7 \%$, dilarang agama $16,7 \%$ dan mahal $4,1 \%$.

Berdasarkan permasalahan mitra diatas, sehingga penulis menganggap perlu melakukan Pengabdian kepada masyarakat "Edukasi kontrasepsi IUD pada akseptor KB di RT 9 Kelurahan Pasar Lama Puskesmas S. Parman Banjarmasin .

\section{TARGET DAN LUARAN}

Target yang dicapai dari kegiatan ini yaitu diketahui gambaran pengetahuan subjek tentang IUD. Terjadinya peningkatan pengetahuan, pemahaman 
mengenai manfaat dan keunggulan kontrasepsi IUD pada akseptor KB di RT 9 Kelurahan Pasar Lama Puskesmas S. Parman Banjarmasin.

\section{METODE PELAKSANAAN \\ Persiapan Kegiatan}

Tahap persiapan dilakukan 2 (dua) kali

Pertemuan meliputi:

a. Pertemuan Pertama dilakukan tanggal 5 Desember 2019 pertemuan pertama yang dilakukan dengan mendatangi ketua RT 9, Kelurahan Pasar Lama untuk menyampaikan surat Tugas, menyampaikan tujuan pelaksanaan dan meminta ijin Pelaksanaan kegiatan Pengabdian masyarakat.

b. Pertemuan kedua dilakukan tanggal 6 Januari 2020, dengan mendatangi ketua RT 9, Kelurahan Pasar Lama untuk melakukan koordinasi tempat dan sasaran yang akan diberi pengetahuan (akseptor KB aktif) dan waktu Pelaksanaan kegiatan

\section{Pelaksanaan Kegiatan}

Tahapan pelaksanaan Pengabdian Kepada Masyarakat (PKM) di Puskesmas S. Parman Banjarmasin adalah sebagai berikut

a. Tanggal 9 Januari 2020

Kegiatan dimulai dengan Registrasi Peserta yang berjumlah 7 orang dilanjutkan melakukan Prestest berupa dengan kuisioner pertanyaan tentang pengetahuan Kontrasepsi IUD pada ibu akseptor KB, RT 9 kelurahan pasar lama dan dilanjutkan dengan pemberian penyuluhan dengan materi Alat kontasepsi secara Umum, manfaat dan efek sampingnya dan efektifitasnya disampaikan oleh Netty S, M.Kes dan faricha hamidatusyifa (Mahasiswa) .

b. Tanggal 10 Januari 2020

Penyuluhan Kontrasepsi IUD, manfaat, efek samping dan efektifitasnya serta sekilas cara pemasangan IUD dg media lembar bolak balik bergambar, disampaikan oleh Husnul Khatimatun
Inayah S.Si.T., M.Kes (Dosen) dan Ayu Dian Pratiwi (Mahasiswa).

c. Tanggal 11 Januari 2020

Mengulang materi penyuluhan yang telah disampaikan dengan tanya jawab dan diskusi disampaikan Ari Widyarni, SKM., M.Kes (dosen) dan Nurul Indah Qariaty, SKM.,M.Kes (dosen) dan dilanjutkan dengan PostTest dengan kuisioner pertanyaan tentang pengetahuan tentang kontrasepsi IUD

\section{Evaluasi kegiatan}

Pelaksanaan evaluasi diakukan dengan cara membandingkan kuisioner pretest dan posttest yg sudah diujikan kepada peserta pelatihan. Kuisioner terdiri dari 10 pertanyaan tentang pengetahuan tentang kontrasepsi IUD pada ibu akseptor KB di RT 9 kelurahan pasar lama.

\section{HASIL DAN PEMBAHASAN}

Dalam hasil pelaksanana Edukasi IUD ini terlihat peningkatan pengetahuan ibu akseptor KB tentang Kontrasepsi IUD dan dapat dilihat dari diagram pada Gambar 1.
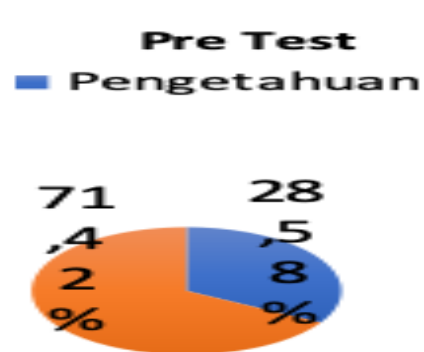

Gambar 1. Diagaram hasil Pre Test pengetahuan Tentang Kontrasepsi IUD pada akseptor KB

Berdasarkan hasil rekap data kuisioner, dar 10 pertanyaan mengenai Alat kontasepsi secara Umum, manfaat dan efek samping dan efektifitas sebelum pemberian materi, terdapat $71,4 \%$ yaitu 5 orang memiiki pengetahuan baik, sedangkan sisanya belum baik. 


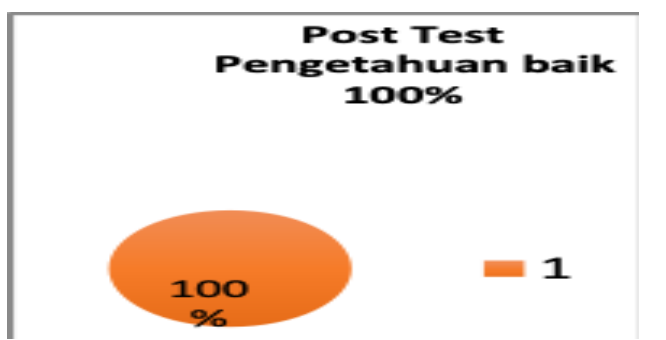

Gambar 2. Diagaram hasil Post Test pengetahuan Tentang Kontrasepsi IUD pada akseptor KB

Berdasarkan hasil post test diketahui terjadi peningkatan, yaitu $100 \%$ peserta memiliki pengetahuan baik.

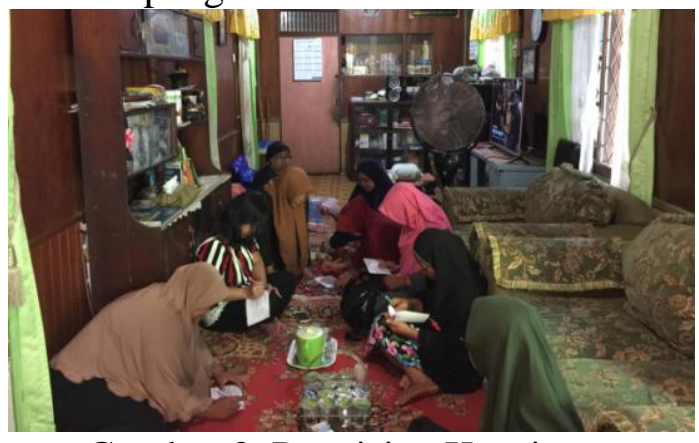

Gambar 3. Pengisian Kuesioner pengetahuan Tentang Kontrasepsi IUD

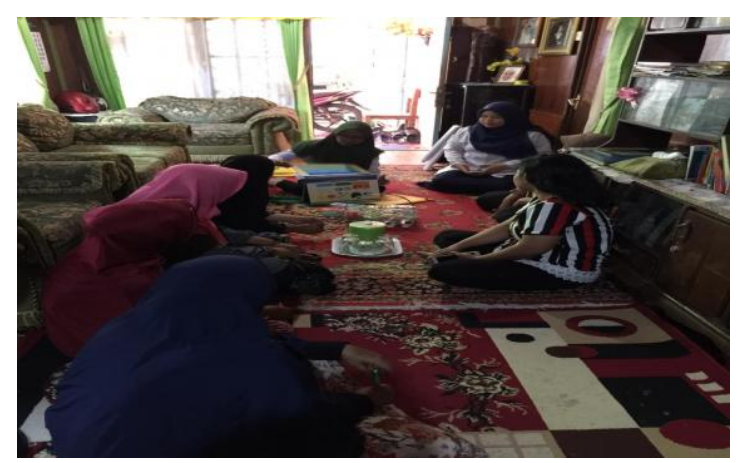

Gambar 4. Pemaparan Kontrasepsi IUD Pada Akseptor KB

\section{KESIMPULAN DAN SARAN}

\section{Kesimpulan}

Berdasarkan hasil kegiatan Pengabdian Kepada Masyarakat berupa edukasi kontrasepsi IUD di Puskesmas S.Parman Banjarmasin, dapat disimpulkan terdapat Peningkatan pengetahuan tentang kontrasepsi IUD untukAkseptor KB dari 71,24\% menjadi $100 \%$ yang berpengetahuan baik. Diharapkan dengan meningkatnya pengetahuan ini akan meningkatkan Pemakaian IUD pada akseptor di RT 9 kelurahan Pasar lama wilayah kerja Puskesmas S.Parman Banjarmasin.

\section{Saran}

Meninjau banyaknya manfaat dari kegiatan Pengabdian masyarakat ini, maka disarankan untuk selanjut perlu Melakukan penyuluhan serupa di puskesmas lainnya terutama bila terdapat masalah yang sama berupa rendahnya pemakaian IUD karena kurangnya pengetahuan Akseptor, Berdasarkan hasil kegiatan PKM ini dapat dikembangkan sebagai bahan penelitian terkait dengan faktor-faktor Pemilihan alat Kontrasepsi, terutama IUD.

\section{DAFTAR PUSTAKA}

Badan Kependudukan dan Keluarga Berencana. 2017. Laporan Program KB Nasional Sistem Informasi Kependudukan \& Keuarga, Banjarmasin : BKKBN

Dinas Kesehatan Kota Banjarmasin. 2017 Profil Kesehatan Kota Banjarmasin Tahun 2016. Banjaramsin : DINKES Kota Banjarmasin

Manuaba, 2012. Ilmu Kebidanan Penyakit Kandungan dan keluarga Berencana Untuk Pendidikan Bidan. Jakarta:EGK.

KemenKes RI. 2013. Buletin Kesehatan Repreduksi, Situasi Keluarga Berencana di Indonesia. Semeter II ISSN 2088 -270x.

Safitri.2020. Peningkatan Kesadaran Masyarakat dalam Penggunaan Alat Kontrasepsi di Kelurahan Kenali Asam Bawah. Jurnal Abdimas Kesehatan. 2(1)21-25. http://dx.doi.org/10.36565/jak.v2i1.87 